\title{
TEKNIK RELAKSASI GENGGAM JARI TERHADAP SKALA NYERI PASIEN POST OPERASI
}

\author{
Tarwiyah $^{1}$, Maulani ${ }^{2, *}$, Rasyidah ${ }^{3}$ \\ 1,2,3 Sekolah Tinggi Ilmu Kesehatan Harapan Ibu, Jambi \\ Email: tarwiyahprastiyo03@gmail.com ${ }^{1}$, mhee114n3@gmail.com ${ }^{2}$, syidahaz84@ gmail.com ${ }^{3}$
}

\begin{abstract}
Abstrak
Tindakan pasca operatif menimbulkan nyeri, penenganan nyeri meliputi dua metode, yaitu penatalaksanaan farmakologi dan non farmakologi. Tingkat nyeri pasca operatif tergantung pada fisiologis dan psikologis individu dan toleransi yang ditimbulkan nyeri. Salah satu terapi non farmakologi yang diberikan dalam penanganan nyeri adalah tehnik genggam jari. Tehnik genggam jari bermanfaat dalam pengelolaan emosi yang akan membuat tubuh menjadi lebi rileks. Penelitian ini menggunakan desain quasy eksperimen dengan rancangan one grup pre-test post-test. Populasi penelitian ini adalah seluruh pasien post operasi berjumlah 36 responden. Penelitian dilakukan di ruang bedah RSUD Raden Mattaher dengan menggunakan tehnik accidental sampling. Analisis data dengan menggunakan analisis univariat dan bivariat dengan uji Wilcoxon. Hasil penelitian menunjukkan rata-rata sebelum dilakukan teknik relaksasi genggam jari adalah 5,50 dan hasil ratarata sesudah dilakukan teknik relaksasi genggam jari adalah 4,00. Hasil bivariat didapatkan $p$ value $=0,000<0,05$. Penelitian ini menunjukkan ada pengaruh teknik relaksasi genggam jari terhadap skala nyeri pasien post operasi.
\end{abstract}

Kata kunci: teknik relaksasi genggam jari, nyeri

\begin{abstract}
Postoperative actions cause pain, pain relief includes two methods, namely pharmacological and non-pharmacological management. The level of postoperative pain depends on the individual's physiology and psychology and the pain caused by pain. One of the non-pharmacological therapies given in the treatment of pain is hand-held technique. Hand-held techniques are useful in managing emotions that will relax the body. The purpose of this study was to determine the effect of hand-held relaxation techniques on the pain scale of postoperative patients. This study used an experimental quasy design with one group pre-test post-test design. The population of this study were all postoperative patients with sample of 36 respondents. The study using accidental sampling technique. Data analysis using univariate and bivariate analysis with Wilcoxon test. The results showed that the average before hand held relaxation technique was 5.50 and the average result after hand held relaxation technique was 4.00. Bivariate results obtained p-value $=0,000$ $<0,05$. So it shows that there is an effect of finger hand relaxation technique on pain scale of postoperative patients.
\end{abstract}

Keywords: hand-held relaxation techniques, pain 


\section{Pendahuluan}

Pasca bedah adalah suatu tindakan pengobatan yang menggunakan cara invasive dengan membuka bagian tubuh yang akan ditangani dengan membuat sayatan dan diakhiri dengan penutupan serta penjahitan luka. Luka tersebut dapat menghasilkan suatu trauma bagi penderita dan menimbulkan keluhan (Sjamsuhidayat., 2010)

Menurut World Health Organization (WHO) tahun 2013 jumlah klien dengan tindakan operasi mencapai angka peningkatan yang sangat signifikan. Pada tahun 2011 terdapat 140 juta klien de seluruh rumah sakit dunia, pada tahun 2012 diperkirakan meningkat hingga mencapai 148 juta jiwa. Menurut (Kemenkes RI, 2013) di Indonesia pada tahun 2012 tindakan operasi mencapai 1,2 juta jiwa.

Setelah post operasi klien mengalami keluhan yang sering muncul diantaranya nyeri. Perawatan pasca bedah sebaiknya segera dilakukan setelah pasien menjalani operasi untuk mengurangi rasa yang tidak nyaman setelah pembedahan. Perawatan pasca bedah tidak hanya terfokus pada organ yang telah dioperasi tetapi juga kesehatan klien secara keseluruhan (Smeltzer \& Bare, 2012)

Dampak yang ditimbulkan pasien apabila nyeri tidak ditangani selama perawatan yaitu nyeri post operasi yang dapat mengakibatkan terganggunya respons fisiologis dengan menunjukkan keberadaan dan sifat nyeri serta ancaman yang potensial terhadap kesejahteraan klien. Efek perilaku biasanya klien mengalami nyeri berdasarkan kata-kata yang diucapkan, gerakan wajah dan respon vocal (Potter, 2005)

Penatalaksanaan nyeri meliputi dua metode, yaitu penatalaksanaan farmakologi dan non farmakologi. Penatalaksanaan nyeri untuk farmakologi melibatkan penggunaan opiat (narkotik), nonopiat/ obat AINS (anti inflamasi nonsteroid), obat-obat adjuvans atau koanalgesik. Penatalaksanaan nyeri secara non farmakologi antara lain Stimulasi dan masase kutaneus, terapi es dan panas, distraksi, tehnik relaksasi, imajinasi terbimbing dan hipnotis. Tehnik relaksasi efektif dalam menurunkan nyeri pasca operasi, karena dapat merefleksikan peran otot-otot pasca operasi bagi kebutuhan klien untuk melakukan tehnik relaksasi tersebut lebih efektif (Potter, 2005).

Tehnik relaksasi napas dalam sering digunakan sebagai penghilang nyeri sebagai salah satu tindakan nonfarmakologis. Keuntungan relaksasi nafas dalam mengurangai rasa cemas, khawatir dan gelisah. Mengurangi tekanan dan memberikan ketahanan yang lebih kuat terhadap penyakit. Kelemahan relaksasi nafas dalam dari factor teknis, factor dari dalam diri konseling, dan faktor dari masalah konseling itu sendiri (Miriam, 2005)

Tehnik relaksasi yang bisa digunakan dalam penurunan intensitas nyeri adalah tehnik relaksasi genggam jari. Untuk mengurangi intensitas nyeri setelah operasi dapat dilakukan tehnik relaksasi genggam jari dimana sangat sederhana dan mudah dilakukan oleh siapapun yang berhubungan dengan jari tangan serta aliran energi didalam tubuh. Menggenggam jari sambil mengatur napas (relaksasi) dilakukan selama kurang lebih 2-5 menit, jari bisa digenggam untuk membawa rasa damai, fokus dan nyaman sehingga dapat menghadapi keadaan dengan perasaan lebih tenang. Titik refleksi pada tangan akan memberikan rangsangan secara refleks (spontan) pada saat genggaman. Keunggulan tehnik relaksasi genggam jari adalah mudah dilakukan, dapat dilakukan oleh siapa saja dan kapan pun. Latihan relaksasi genggam jari dapat dilakukan sendiri dan sangat membantu dalam kehidupan sehari-hari untuk merilekskan ketegangan fisik (Hill, 2011)

Mekanisme dari relaksasi genggam jari ini adalah menggenggam jari sambil menarik nafas dalam dalam (relaksasi) sehingga dapat mengurangi dan menyembuhkan ketegangan fisik dan emosi, karena genggaman jari akan menghangatkan titik-titik keluar dan masuknya energi pada meridian (energi channel) yang terletak pada jari tangan kita (Cane, 2013) 
Hasil penelitian yang dilakukan oleh (Ma'rifah, 2015) tentang efektifitas relaksasi genggam jari terhadap penurunan skala nyeri pada pasien post operasi sectio caesarea di RSUD Prof. DR. Margono Soekardjo Purwokerto menunjukkan pada kelompok eksperiment ada pengaruh tehnik relaksasi genggam jari. Penelitian (Rahmat., 2016) bahwa tehnik genggam jari dapat menurunkan intensitas nyeri dengan perbedaan nyeri sebelum dan sesudah diberikan intervensi terdapat pengaruh tehnik genggam jari terhadap penurunan intensitas nyeri pada pasien post operasi apendiktomy di RS DR. Reksodiwiryo. Berdasarkan latar belakang tersebut diatas, peneliti tertarik untuk melakukan penelitian mengenai pengaruh tehnik relaksasi genggam terhadap skala nyeri pasien post operasi.

\section{Metode Penelitian}

Desain penelitian ini menggunakan Quasy Eksperimen yang bertujuan untuk mengetahui pengaruh yang ditimbulkan sebagai akibat dari adanya perlakuan tertentu. Rancangan penelitian ini dengan desain "one grup pre-test post-test" yang bertujuan untuk mengetahui pengaruh teknik relaksasi genggam jari terhadap skala nyeri pasien post operasi.

Penelitian ini dilakukan di ruang bedah RSUD Raden Mattaher. Populasi dalam penelitian adalah seluruh pasien post operasi di RSUD Raden Mattaher Jambi dengan jumlah sample sebanyak 36 responden. Pendekatan sampling yang digunakan dalam penelitian ini adalah accidental sampling. Data dianalisis dengan menggunakan analisis univariat dan bivariat dengan menggunakan uji Wilcoxon.

\section{Hasil dan Pembahasan}

1. Skala nyeri sebelum dan sesudah dilakukan intervensi

Sebelum responden diberikan terapi relaksasi genggam jari, terlebih dahulu dilakukan pengukuran skala nyeri (pre) kemudian setelah diberikan intervensi selama 20 menit dilakukan pengukuran kembali skala nyeri (post) dengan menggunakan lembar observasi dan NRS (Numeric Rating Scale).

Tabel 1. Skala nyeri responden sebelum dan sesudah dilakukan intervensi pada pasien post operasi

\begin{tabular}{ccccc}
\hline Skala Nyeri & \multicolumn{2}{c}{ Sebelum } & \multicolumn{2}{c}{ Sesudah } \\
\cline { 2 - 5 } & $\mathrm{n}$ & $\%$ & $\mathrm{n}$ & $\%$ \\
\hline Ringan & 0 & 0 & 27 & 25,0 \\
Sedang & 36 & 100 & 36 & 75,0 \\
\hline Jumlah & 36 & $100 \%$ & $100 \%$ \\
\hline
\end{tabular}

Berdasarkan tabel diatas dari 36 responden diketahui rata-rata skala nyeri sebelum dilakukan intervensi adalah nyeri sedang $(100 \%)$, setelah dilakukan intervensi didapatkan $27(75,0 \%)$ responden berada pada nyeri sedang dan $9(25,0 \%)$ responden mengalami nyeri ringan. 
Dampak nyeri yang dirasakan pasien post operasi mengakibatkan efek perilaku biasanya klien mengalami nyeri berdasarkan kata-kata yang diucapkan, gerakan wajah dan respon vocal. Berpengaruh terhadap aktivitas sehari-hari dimana klien tidak mampu mencukupi kebutuhan aktivitas sehari-hari secara mandiri (Potter, 2005)

Hasil penelitian skala nyeri yang dirasakan responden berbeda-beda. Faktor yang mempengaruhi ambang nyeri seseorang biasanya dikaitkan dengan pengalaman masa lalu. Responden yang sudah biasa mengalami nyeri pada nyeri selanjutnya akan mengalami nyeri sedang atau ringan. Hal ini terjadi karena tingkat toleransi pada pasien terhadap nyeri lebih tinggi. Mudah tidaknya seseorang mengatasi nyeri tergantung pengalaman di masa lalu dalam mengatasi nyeri.

Setelah dilakukan intervensi, skala nyeri pada pasien post operasi memiliki nyeri sedang yang lebih dominan dibanding nyeri ringan maupun berat. Dari penelitian tersebut terdapat penurunan skala nyeri hanya 9 orang yang mengalami nyeri ringan. 27 responden tetap berada di skala nyeri sedang. Hal ini bisa dipengaruhi oleh beberapa faktor diantaranya waktu diberikan kurang efektif, usia seseorang mampu mempengaruhi adanya tingkat stimulus ketenangan tersebut, pengalaman masa lalu yang sudah mengalami operasi sebelumnya.

Penelitian yang dilakukan oleh (Sulung., 2017) tentang tehnik relaksasi genggam jari terhadap intensitas nyeri pada pasien post appendiktomi dengan skala nyeri sebelum diberikan intervensi 4-6. Setelah dilakukan perlakuan didapatkan hasil 3-5. Maka dapat disimpulkan pada penelitian ini bahwa setelah dilakukan intervensi skala nyeri pada pasien post appendiktomi tampak berpengaruh dalam menurunkan skala nyeri. Penelitian (Pinandita, 2012) yang meneliti tentang skala nyeri setelah diberikan tehnik relaksasi genggam jari skala nyeri yang dirasakan pasien dari skala nyeri pada pre test dengan hasil 6,64 dan post test 4,88 . Hasil penelitian ini juga menunjukkan ada perbedaan antara pre dan post dengan perlakuan relaksasi genggam jari terhadap penurunan skala nyeri.

Relaksasi genggam jari menghasilkan impuls yang dikirim melalui serabut saraf aferen non-noniseptor. Sehingga intensitas nyeri akan berubah atau mengalami modulasi akibat stimulasi relaksasi genggam jari yang lebih dahulu dan lebih banyak mencapai otak. Relaksasi genggam jari dapat mengendalikan dan mengembalikan emosi yang akan membuat tubuh menjadi rileks. Adanya stimulasi pada luka bedah menyebabkan keluarnya mediator nyeri yang akan menstimulasi transmisi impuls di sepanjang serabut aferen non-noniseptor ke substansi gelatinosa (pintu gerbang) di medulla spinalis untuk selanjutnya melewati thalamus kemudian disampaikan ke kortek serebri dan di interpretasikan sebagai nyeri. Serabut saraf aferen non-noniseptor mengakibatkan "gerbang" tertutup sehingga stimulus pada kortek serbri dihambat atau dikurangi akibat counter stimulasi relaksasi mengenggam jari. Gerbang dapat ditemukan di sel-sel diujung sumsum tulang belakang, thalamus dan serebrum. Dengan memahami apa yang dapat mempengaruhi gerbang/gerbang-gerbang, perawat dapat memperoleh kerangka kerja konseptual yang berguna untuk manajemen nyeri (Hill, 2011)

2. Pengaruh tehnik relaksasi genggam jari terhadap skala nyeri responden sebelum dan sesudah intervensi pada pasien post operasi

Tabel 1. Pengaruh tehnik relaksasi genggam jari terhadap skala nyeri responden sebelum dan sesudah intervensi pada pasien post operasi

\begin{tabular}{ccccc}
\hline Kelompok & $\mathrm{n}$ & Variabel & Median (min-mak) & $\mathrm{P}$ \\
\hline Intervensi & 36 & Pre test & $5,50(4-7)$ & 0,000 \\
\hline
\end{tabular}


Berdasarkan hasil analisis statistik menggunakan uji Wilcoxon pada pengukuran skala nyeri sebelum tehnik relaksasi genggam jari diketahui rata-rata skala nyeri 5,50 dan setelah dilakukan intervensi didapatkan rata-rata skala nyeri 4,00 , dengan nilai rata-rata penurunan skala nyeri 1,50. Hasil uji statistik didapatkan $p-0,000$ ( $p$-value $<0,05)$, maka dapat disimpulkan ada pengaruh tehnik relaksasi genggam jari terhadap skala nyeri pasien post operasi.

Hasil penelitian menunjukkan bahwa hasil uji pada kelompok pretest -posttest diketahui nilai rata-rata (mean) adalah 1.50 yang menunjukkan nilai sig. 0,000 dengan derajat kemaknaan 0,05. Hasil sig. 0,000 < 0,05 yang artinya ada pengaruh tehnik relaksasi genggam jari terhadap skala nyeri pasien post operasi.

Penelitian ini sejalan dengan penelitian sebelumnya effect of handheld finger relaxation on reduction of pain intensity in patients with post-appendectomy at patient ward. Ada perbedaan menunjukkan bahwa pengaruh yang bermakna secara statistic antara tingkat nyeri responden yang diberikan tehnik relaksasi genggam jari nilai p-valeu 0,001 (Yuliastuti, 2015). Penelitian (Karokaro, 2015) menunjukkan bahwa pengaruh tehnik relaksasi genggam jari terhadap penurunan intensitas nyeri pada pasien post operasi laparatomi. Ada perbedaan pengaruh yang bermakna secara statistic antara skala nyeri pada tehnik relaksasi genggam jari terhadap intensitas nyeri p-value 0,000 .

Menggenggam jari sambil menarik napas dalam dapat mengurangi dan menyembuhkan tegangan fisik serta emosi, karena genggaman jari akan menghangatkan titik keluar dan masuknya energy pada jari tangan. Titik-titik refleksi pada tangan akan memberikan rangsangan secara refleks pada saat genggaman. Rangsangan tersebut akan mengalirkan semacam gelombang kejut atau listrik menuju otak. Gelombang tersebut diterima otak dan diproses dengan cepat, lalu diteruskan menuju saraf pada organ tubuh yang mengalami gangguan, sehingga sumbatan di jalur energi menjadi lancar, maka tidak ada nyeri yang dirasakan atau nyeri menjadi menurun/hilang (Hill, 2011).

Pada penelitian ini didapatkan $36(100 \%)$ responden mengalami penurunan skala nyeri dikarenakan beberapa faktor yang dapat menyebabkan penurunan skala nyeri diantaranya dari tehnik genggam jari yang diberikan, waktu dan cara melakukan dengan tepat, adanya penjelasan tentang manfaat dan tujuan dari tehnik relaksasi genggam jari sehingga responden yakin bahwa menggunakan tehnik relaksasi genggam jari dapat menurunkan skala nyeri, selain itu juga tehnik relaksasi genggam jari tidak memiliki efek sampingnya, sehingga tehnik relaksasi genggam jari sangat baik untuk diterapkan bagi pasien yang mengalami nyeri. Hasil penelitian ini diketahui bahwa efektivitas tehnik genggam jari untuk menurunkan skala nyeri dapat dirasakan setelah 20 menit setelah pemberian tehnik relaksasi genggam jari.

\section{Kesimpulan}

Berdasarkan hasil penelitian tentang pengaruh teknik relaksasi genggam jari terhadap skala nyeri pasien post operasi maka dapat ditarik kesimpulan yang menunjukkan skala nyeri sebelum diberikan intervensi didapatkan nilai mean 5.50. skala nyeri sesudah dilakukan relaksasi genggam jari didapatkan nilai rata-rata 4.00. Hasil uji pada kelompok pretest-posttest diketahui nilai rata-rata (mean) adalah 1.50 yang menunjukkan nilai sig. 0,000 dengan derajat kemaknaan 0,05 . Hasil sig. $0,000<0,05$ yang artinya ada pengaruh 
skala nyeri sebelum dan sesudah dilakukan relaksasi genggam jari terhadap skala nyeri pasien post operasi.

\section{Referensi}

Cane, P. (2013). Hidup Sehat dan Selaras: Penyembuhan Trauma. (L. Maria, s \& Emmy, Ed.). Yogyakarta: capacitar international, INC.

Hill, R. (2011). Nursing From The Inside-Out. Living And Nursing From The Highest Point Of Your Consciousness. London: Jones and Batlett Publishers.

Karokaro, M. (2015). Pengaruh Tehnik Relaksasi Genggam Jari Terhadap Penurunan Intensitas Nyeri Pada Pasien Post Operasi Laparatomi Di Rumah Sakit Umum Daerah (RSUD) Deli Serdang Lubuk Pakam, 3. No 4 De.

Kemenkes RI. (2013). Riset Kesehatan Dasar. Jakarta: Badan Penelitian dan Pengembangan Kesehatan Kementrian Kesehatan RI.

Ma'rifah, D. (2015). Pengaruh Tehnik Relaksasi Genggam Jari Terhadap Efektifitas Relaksasi Genggam Jari Terhadap Penurunan Skala Nyeri Pada Pasien Post Operasi Section Caesarea Di RSUD Prof. Dr. Margono Soekardjo Purwokerto. Jurnal Keperawatan 'Aisyiyah, 2 No.1, 63-67.

Miriam, B. \&. (2005). Respon Relaksasi. Teknik Meditasi Sederhana dan Untuk Mengatasi Tekanan Hidup. Jakarta: Kaifa.

Pinandita, D. (2012). Pengaruh Tehnik Relaksasi Genggam Jari Terhadap Penurunan Intensitas Nyeri Pada Pasien Post Operasi Laparatomi. Jurnal Ilmiah Kesehatan Keperawatan, Vol 8. No.

Potter, P. \&. (2005). Buku Ajar Fundamental Keperawatan, Konsep, Proses, dan Praktik (Edisi 4 Vo). Jakarta: EGC.

Rahmat., A. \&. Pengaruh Teknik Relaksasi Genggam Jari Terhadap Penurunan Intensitas Nyeri Pasien Post Operasi Apendiktomy Di Rs Dr. Reksodiwiryo (2016).

Sjamsuhidayat. (2010). Buku Ajar Ilmu Bedah. (Edisi II). Jakarta: EGC.

Smeltzer \& Bare. (2012). Buku Ajar Keperawatan Medikal Bedah (VIII). Jakarta: EGC.

Sulung., S. \&. (2017). Tehnik Relaksasi Genggam Jari Terhadap Intensitas Nyeri Pada Pasien Post Appendiktomi. Jurnal Endurance, 2 (3), Hal: 397-405.

Yuliastuti, C. (2015). Effect Of Handheld Finger Relaxation On Reduction Of Pain Intensity In Patients With Post-Appendectomy At Inpatient Ward, RSUD Sidoarjo, 5 (3), 53-58. 